\title{
Validity of instruments used in nursing care for people with skin lesions
}

Validade de instrumentos sobre o cuidado de enfermagem à pessoa com lesão cutânea

Roberta Kaliny de Souza Costa ${ }^{1}$

Gilson de Vasconcelos Torres ${ }^{2}$

Marina de Góes Salvetti ${ }^{2}$

Isabelle Campos de Azevedo ${ }^{1}$

Maria Antônia Teixeira da Costa ${ }^{1}$

Keywords

Nursing assessment; Nursing care; Validation studies; Wound healing; Skin/

injuries

Descritores

Avaliação em enfermagem; Cuidados de enfermagem; Estudos de validação; Cicatrização; Pele/lesões

Submitted June 25, 2014

Accepted July 29, 2014
Corresponding author Roberta Kaliny de Souza Costa André Sales street, 667, Caicó, RN, Brazil. Zip Code: 59300-000 robertaksc@bol.com.br

\section{DOI}

http://dx.doi.org/10.1590/1982-

0194201400074

\section{Abstract}

Objective: To validate the content of two instruments used to evaluate nursing care for people with skin lesions.

Methods: Content validation study comprised of two stages: the first was the development of the instruments, beginning with a literature review; the second, content validation by means of an evaluation conducted by 30 judges/experts. For analysis, the Kappa coefficient $\geq 0.61$ and content validity index $\geq 0.75$ were adopted. Results: The judges presented nine suggestions regarding the instrument's categories. All items of the questionnaire and the observation script reached acceptable rates of content validity and concordance. Some categories attained scores above the given value, confirming the validity of the content.

Conclusion: The instruments showed satisfactory content validity rates, and can be used to measure the skills and knowledge of nursing care provided to people with skin lesions.

\section{Resumo}

Objetivo: Verificar a validade do conteúdo de dois instrumentos para avaliar o cuidado de enfermagem à pessoa com lesão cutânea.

Métodos: Pesquisa de validação de conteúdo que compreendeu duas etapas: a primeira foi a elaboração dos instrumentos, a partir de uma revisão da literatura; a segunda, de validação de conteúdo, mediante a avaliação dos instrumentos por 30 juízes/especialistas. Para análise, adotaram-se coeficiente Kappa $\geq 0,61$ e índice de validade de conteúdo $\geq 0,75$.

Resultados: Na avaliação das categorias de composição dos instrumentos, verificaram-se nove sugestões indicadas pelos juízes. Todos os itens do questionário e do roteiro de observação obtiveram índices aceitáveis de validade de conteúdo e de concordância. Algumas categorias alcançaram escores acima do valor determinado, confirmando a validade de conteúdo.

Conclusão: Os instrumentos apresentaram índice de validade de conteúdo satisfatório, e podem ser utilizados para avaliar a habilidade e o conhecimento sobre o cuidado de enfermagem à pessoa com lesão cutânea.

\footnotetext{
'Universidade do Estado do Rio Grande do Norte, Caicó, RN, Brazil.

2Universidade Federal do Rio Grande do Norte, Natal, RN, Brazil.

Conflicts of interest: there are no conflicts of interest to declare.
} 


\section{Introduction}

Wounds are among the most common skin problems in everyday health care services. With high incidence and prevalence in the population, skin lesions cause great harm to the lives of individuals and their families, and cause economic impact on health care services. ${ }^{(1)}$

The quality of care for people with wounds requires comprehensive care provided by trained professionals, and systematized by protocols that guide the practice of preventive, diagnostic and treatment conduct.

As members of the health care team, nurses play an important role in treating this clientele, diagnosing the problem, monitoring its evolution, and applying dressings at home and at health services.

(2) Performance evaluation should seek to grasp the knowledge acquired by future professionals, in addition to identifying their ability to perform specific tasks, using, integrating and applying their learned theory to solving problems in real situations.

The instruments for this type of evaluation should be grounded in scientific evidence, essential to the quality, legitimacy and credibility sought in its validation process. ${ }^{(3)}$

The validation of an instrument verified its ability to measure a phenomenon, and may be performed using various methods. In turn, content validation is one of the psychometric measures essential to the development of measurement tools, which involves the process of preparation and trial by experts, in defining the theoretical universe and different dimensions of the concept to be observed and measured. ${ }^{(4)}$

Thus, the use of reliable instruments is a valuable resource in the evaluation of nursing care, especially during professional training, since it facilitates the production of data, favors the analysis of techniques and approaches adopted, and provides standardization of efficient conduct in teaching and clinical practice.

However, the lack of validated measurement tools in literature to evaluate nursing care for people with skin lesions reinforces the importance of constructing and validating tools for this purpose.
Thus, this study aimed to validate the content of two instruments that evaluate nursing care for people with skin lesions.

\section{Methods}

Content validation was comprised of two stages: the first was the development of the instruments, beginning with a literature review; the second, content validation by means of evaluation of the instruments by 30 experts.

The judges were selected by performing an advanced search on Plataforma Lattes, which is a database containing researchers' curricula vitae (CVs). The search yielded 1,449 CVs, from which a purposive sample of 147 nurses was selected, based on the following inclusion criteria: having a $\mathrm{PhD}$ or master's degree in health sciences; working in undergraduate teaching; and having engaged in scientific research and/or publication on wounds over the last five years.

An invitation letter was sent by email to the 147 nurses, containing the objectives and methodology of the study, the rationale of the validation process and request for participation in the study as an evaluating judge. The letter also provided a link to a form developed in Google docs (docs. google.com), which the nurses should use for the evaluations. Of the 147 professionals invited, 30 agreed to participate, thereby constituting the study sample.

The data collection instrument sent to the judges was comprised of three parts: identification of professional characterization items; a structured, checklist-type observation script; and a questionnaire with ten multiple-choice questions to assess knowledge of nursing care for patients with wounds.

In general terms, the content of the questionnaire considered the categories comprising the checklist. The checklist included 20 items corresponding to the steps deemed important for nursing care of people with skin lesions.

The evaluation by the judges consisted of rating each item on the instrument as well as the in- 
strument as a whole as "adequate" or "inadequate," according to the following criteria: usefulness/relevance, consistency, clarity, objectivity, simplicity, feasibility, if it is up-to-date, vocabulary, accuracy and sequence of instruction topics. Furthermore, explanations of the inadequacies and suggestions could also be made so that items could be modified and improved.

After evaluation of the instruments, the Kappa coefficient and Content Validity Index were applied to verify the level of agreement of the judges in relation to the items evaluated. As criteria for acceptance, an agreement level of $>0.61$ (good level) for the Kappa coefficient and $\geq 0.75$ for the Content Validity Index was established for the evaluation of each item, as well as for the general evaluation of each instrument. ${ }^{(5.6)}$

The data collected were organized into an electronic spreadsheet and exported to statistical software. After coding and tabulation, the data were analyzed using descriptive statistics, with absolute and relative frequencies, application of the Kappa test and the Content Validity Index. The analysis supported the reformulation of instruments in accordance with the guidelines and suggestions of the judges.
The development of the study adhered to national and international standards of ethics in research involving humans.

\section{Results}

Thirty nurses participated as judges. The majority $(80 \%)$ was female, and their ages ranged between 25 and 59 years, with a mean age of 44.3 years. As regards professional qualifications, the majority had doctorate degrees (76.7\%), experience in teaching and care $(93.3 \%)$, and worked in the Southeast $(56.7 \%)$ of the country.

The length of experience in health care ranged from one to 30 years, the mean being 12.8 years; the period of work as a teacher ranged from one to 35 years, the mean being 15.3 years, with the predominant ranges from one to 10 years and 11-20 years of experience.

In evaluating the composition categories of the instruments on nursing care for people with lesions, nine suggestions given by the judges were verified, of which five were adopted and four rejected by the researcher after analysis and comparison with the literature (Chart 1).

Chart 1. Suggestions of the judges, acceptance and rejection of suggestions, and justification by the researcher

\begin{tabular}{|c|c|c|c|}
\hline Category of instrument & Suggestions of judges (n) & Acceptance & Justification \\
\hline Initial observations & $\begin{array}{l}\text { Uses accessible language when } \\
\text { addressing the person with lesion }{ }^{(1)}\end{array}$ & Yes & $\begin{array}{l}\text { Verbal communication in a language that is familiar to the patient is important so that he or } \\
\text { she can understand the information provided to them, enabling the fulfillment of the delegated } \\
\text { actions to ensure successful treatment }{ }^{(7)}\end{array}$ \\
\hline \multirow[t]{3}{*}{$\begin{array}{l}\text { Assessment of the person and skin } \\
\text { lesion }\end{array}$} & $\begin{array}{l}\text { Combines the items "Identify risk factors" } \\
\text { and "Perform patient history"(1) }\end{array}$ & No & $\begin{array}{l}\text { In the constitution of care guidelines for people with skin lesions, the identification of risk factors } \\
\text { appears as a separate item of the patient history }{ }^{\left({ }^{8}\right)}\end{array}$ \\
\hline & Includes directed physical exam ${ }^{(5)}$ & No & $\begin{array}{l}\text { Authors refer to the performance of a complete and detailed physical examination of the person } \\
\text { with skin lesion }{ }^{(8.9)}\end{array}$ \\
\hline & $\begin{array}{l}\text { When evaluating the lesion, specifies the } \\
\text { volume, depth and width measurements }{ }^{(3)}\end{array}$ & Yes & $\begin{array}{l}\text { The measurements will be specified and standardized to facilitate the implementation of the } \\
\text { instrument }\end{array}$ \\
\hline \multirow[t]{2}{*}{$\begin{array}{l}\text { Care of the wound and surrounding } \\
\text { skin }\end{array}$} & $\begin{array}{l}\text { Does not describe the saline jet stream } \\
\text { technique to clean the lesion }{ }^{(1)}\end{array}$ & No & Technique described in literature $\mathrm{r}^{(10,11)}$ \\
\hline & $\begin{array}{l}\text { When applying the dressing, divides the } \\
\text { item into clean and sterile techniques }{ }^{(3)}\end{array}$ & No & $\begin{array}{l}\text { We opted for the sterile technique, since the instrument will be collected in hospitals and health } \\
\text { care units. In the environment of health care services, sterile technique should be used }{ }^{(10)}\end{array}$ \\
\hline $\begin{array}{l}\text { Follow-up and guidance to people with } \\
\text { skin lesions and their relative/caregiver }\end{array}$ & $\begin{array}{l}\text { Includes nutrition guidance in health } \\
\text { education actions for people with skin } \\
\text { lesions }{ }^{(1)}\end{array}$ & Yes & The guidelines should include the benefits of eating certain foods that are important to health ${ }^{(12)}$ \\
\hline Records and documentation & $\begin{array}{l}\text { Makes a record of the use of popular } \\
\text { practices }^{(1)}\end{array}$ & Yes & There are several popular therapies that are used in wound care ${ }^{(12)}$ \\
\hline Final observations & $\begin{array}{l}\text { In the item relating to organization of the } \\
\text { environment, provides details regarding } \\
\text { the procedures used to organize the } \\
\text { environment(5) }\end{array}$ & Yes & $\begin{array}{l}\text { The details of the procedures involved in organization of the environment, after treatment of a } \\
\text { person with skin lesion, standardizes and facilitates application of the instrument }\end{array}$ \\
\hline
\end{tabular}

The number of judges that suggested changes in the categories that compose the instruments is indicated by " $\mathrm{n}$ " 
Table 1. Analysis of concordance of the judges on the categories of the checklist

\begin{tabular}{|c|c|c|}
\hline \multirow{2}{*}{ Categories comprising the checklist } & \multicolumn{2}{|c|}{ Concordance analysis } \\
\hline & Kappa & CVI \\
\hline \multicolumn{3}{|l|}{ Initial observations } \\
\hline Initial Care & 0.76 & 0.87 \\
\hline Sanitizes hands & 0.73 & 0.84 \\
\hline \multicolumn{3}{|l|}{ Assessment of the person and skin lesion } \\
\hline Medical history taking & 0.78 & 0.87 \\
\hline Identifies risk factors & 0.74 & 0.85 \\
\hline Performs physical examination & 0.73 & 0.84 \\
\hline Checks vital signs & 0.78 & 0.88 \\
\hline Assesses the presence of pain & 0.77 & 0.87 \\
\hline Evaluates the skin lesion & 0.72 & 0.83 \\
\hline Identifies signs of infection & 0.76 & 0.85 \\
\hline Identifies the need for, and provides exams & 0.82 & 0.90 \\
\hline \multicolumn{3}{|l|}{ Care of lesion and surrounding skin } \\
\hline Cleans wound & 0.65 & 0.78 \\
\hline Applies dressing & 0.66 & 0.78 \\
\hline Assesses the need for debridement & 0.79 & 0.87 \\
\hline Recommends coverage & 0.81 & 0.89 \\
\hline \multicolumn{3}{|c|}{ Referral and guidance to the person with skin lesion, relative/caregiver } \\
\hline Develops educational activities & 0.85 & 0.91 \\
\hline Identifies and provides referral & 0.84 & 0.91 \\
\hline \multicolumn{3}{|l|}{ Record and documentation } \\
\hline Records clinical evaluation & 0.81 & 0.89 \\
\hline Records lesion evaluation & 0.82 & 0.89 \\
\hline \multicolumn{3}{|l|}{ Final observations } \\
\hline Organizes the environment & 0.74 & 0.85 \\
\hline Sanitizes hands after care & 0.80 & 0.88 \\
\hline
\end{tabular}

CVI - Content Validity Index

In the result of the judgment of the observation checklist on nursing care for patients with skin lesions, all items showed concordance within the prescribed level (Content Validity Index $>0.75$ and Kappa coefficient $>0.61)$. However, some categories achieved excellent Kappa coefficients ( $>0.80)$ among the study judges, such as: Identifies the need and provides additional tests; Recommends coverage; Develops educational activities; Identifies the need for and provides referral; Records the clinical evaluation; and Records the evaluation of the lesion. Most items presented a Content Validity Index well above the given value, except for the following categories: Cleans the wound and Applies dressing (Content Validity Index of 0.78 ). Both items also had the lowest Kappa value of the instrument ( 0.65 and 0.66 , respectively) (Table 1$)$.

In the analysis of concordance of the judges on the questions of the questionnaire on knowledge of nursing care for people with lesion, it is observed that all of the questions had Kappa and Content Validity Index values within the minimum level adopted. Questions Q2, Q3, Q6, Q7, Q9 and Q10 attained excellent Kappa values $(>0.80)$. The lowest levels of concordance among the judges were on questions Q1, Q4, Q5 and Q8. The Content Validity Index was much higher $(\geq 0.90)$ than the given value on questions Q6, Q7, Q9 and Q10 (Table 2).

The final version of the instruments is in the appendix. 
Table 2. Judges' analysis of concordance regarding the knowledge questionnaire categories

\begin{tabular}{|c|c|c|}
\hline \multirow{2}{*}{ Categories comprising the checklist } & \multicolumn{2}{|c|}{ Agreement analysis } \\
\hline & Kappa & CVI \\
\hline Q1. What actions should be taken in the evaluation stage of a person with skin lesion? & 0.76 & 0.86 \\
\hline Q2. Which aspects should be considered when evaluating the characteristics of the skin lesion? & 0.81 & 0.89 \\
\hline Q3. Which signs of infection should be considered when evaluating the characteristics of the skin lesion? & 0.82 & 0.89 \\
\hline Q4. Which aspects should be considered when choosing the dressing to be applied onto the skin lesion? & 0.71 & 0.81 \\
\hline Q5. During the care of the wound and surrounding skin, what is the adequate procedure to perform during application of the dressing? & 0.78 & 0.87 \\
\hline $\begin{array}{l}\text { Q6. In the initial and subsequent evaluation of the skin lesion, the nurse should be aware of the wound characteristics that indicate the need to perform } \\
\text { debridement. What are these characteristics? }\end{array}$ & 0.83 & 0.90 \\
\hline Q7. When recommending the coverage to be used in the treatment of the lesion, what should the nurse consider? & 0.86 & 0.92 \\
\hline Q8. What debriding action products are used in the topical treatment of skin lesions? & 0.76 & 0.86 \\
\hline Q9. What guidelines should be provided to the person with skin lesions and their relative/caregiver for continuing care? & 0.82 & 0.90 \\
\hline Q10. When completing the record and documentation of the care process for a person with lesion, what should be done? & 0.86 & 0.92 \\
\hline
\end{tabular}

Q - Question; CVI - Content Validity Index.

\section{Discussion}

The results of this study show the type of validation used as being a limitation, considering the opinions of the judges and their concordance on the content of instruments to assess nursing care for the person with wounds.

This type of evaluation must be grounded on the best sources of scientific evidence. Instruments evaluated by experts are an important tool, with the potential to contribute to nurses' practice in teaching and care of this population.

Care of a person with skin lesions includes a range of preventive, diagnostic and therapeutic measures, requiring intervention by a trained health professional to care for the patient comprehensively, considering their individuality and specifics of the wound. Reinforcing this idea, an increasing number of studies have shown the need for the health care system to care for people with lesions, with guidelines and protocols that support decision-making and guide professional practice. ${ }^{(2,13)}$

The active and organized work process of nursing care for people with lesions should be practiced in services, and taught in undergraduate courses, contributing to the quality of care and preparation of the professional to act in this context. ${ }^{(14)}$

Corroborating the opinions of the judges participating in the research, one study ${ }^{(13)}$ that char- acterizes care protocols for people with wounds in Brazil showed that activities involved in evaluating the person and the wound, care of the wound and the surrounding skin, documentation and recording of clinical findings, and referral and education of the person, family member and/or caregiver are all important elements in the comprehensiveness of recommendations and guidelines for care of people with skin lesions.

With regard to procedures prior to evaluation of the people and their wounds, there was good concordance among the judges on items focused on receiving the person with lesions, preservation of privacy, hand hygiene and explanation and request for permission to perform procedures.

Evaluation of a person and their wound corresponds to an initial and important stage of care, crucial to the preparation and implementation of treatment aimed at restoring skin health and recovery of the person with lesion. This requires knowledge, communication skills, observation of health needs and care, and performance of propaedeutic techniques.

Among the procedures considered in this stage of care that achieved concordance among the judges, the following are highlighted: a thorough medical history taking and detailed physical examination; the existence of risk factors; checking vital signs and for presence of pain associated with the lesion; and signs of infection and laboratory in- 
vestigation. These actions are considered crucial in identifying the health condition of the patient and diagnosing the wound, because they encourage detection of associated diseases and problems related to the healing process. ${ }^{(13)}$

Once the survey of a patient's condition and wound characteristics is complete, the development of the diagnosis of care needs proceeds, related to the physical and psychological dimensions of the person with a wound, essential to planning the actions to be implemented in treatment. In this stage of care, consonance between the judges and the literature was verified regarding the application of procedures involved in the skin restoration process, such as cleaning the lesion, need for debridement of the wound, application of dressings and recommendation for topical therapy to be used in treatment. ${ }^{(15)}$

In this study, the items related to cleaning the lesion and the dressing had the lowest concordance rates among the judges. In these items, the description of the parameter to be evaluated was questioned regarding the use of irrigation of the lesion with $0.9 \%$ saline solution jets. Suggestions for improvement were also identified in order to define the use of a clean or sterile technique, considering closure intention (primary, secondary and tertiary healing).

The criticisms made by the judges highlighted the need for production of best scientific evidence regarding procedures and techniques involved in care of people with skin lesions, as scarcity and low level of evidence in publications regarding this subject is observed. This contributes to the persistence of doubts and an incongruous variety of procedures for evaluation and treatment of the problem.

In aspects regarding the set of therapeutic measures, there was high concordance among the judges regarding strategies for referral and guidance of people with skin lesions, family member and/or caregiver. Care of patients with wounds requires multidisciplinary health intervention and ongoing educational work, involving the health care team, patients, family members and caregivers. ${ }^{(13)}$
Furthermore, it is noteworthy that all monitoring of a person with lesion, including successive evaluations, effectiveness of conduct, guidance, training, products and therapeutic techniques used at various stages of care, should be documented and recorded, encouraging communication between the multidisciplinary team, and providing diagnostic and therapeutic benefits. ${ }^{(13,16)}$

Nurses represent the largest number of workers in health care institutions, directly aimed at caring for patients with skin wounds. It is therefore crucial that nurses are trained to perform appropriate care.

In this sense, the use of instruments for evaluating the care provided to people with lesions are capable of assisting in the guidance of care practice and teaching, and is a strategy for organizing the work of diagnosis, treatment and prevention of people with lesion, with a view towards a holistic approach that considers the individual as a whole, beyond the healing of her or his lesion.

\section{Conclusion}

The instruments showed a satisfactory content validity index, and can be used to measure the ability and knowledge of nursing care provided to people with skin lesions.

\section{Acknowledgments}

To the Coordination of Improvement of Higher Education Personnel and the State University of Rio Grande do Norte (CAPES; UERN; doctoral scholarship for Roberta Kaliny de Souza Costa and CAPES/PNPD postdoctoral scholarship for Marina de Góes Salvetti).

\section{Collaborations}

Costa RKS; Azevedo IC and Torres GV contributed to the design, analysis and interpretation of data, drafting the article and critical review of the manuscript. GV Torres; Salvetti MG and Costa MAT contributed to critical review of the manuscript and approved the final content. 


\section{References}

1. Waidman MA, Rocha SC, Correa JL, Brischiliari A, Marcon SS. [Daily routines for individuals with a chronic wound and their mental health]. Texto \& Contexto Enferm. 2011; 20(4):691-9. Portuguese.

2. Torres GV, Mendes FR, Mendes AF, Silva A0, Torres SM, Viana DM, et al. [Nurses' evaluation about primary health care of users with venous ulcers: study in Évora, Portugal]. Rev Enferm UFPE. 2011; 5(Spe):38898. Portuguese.

3. Bittencourt HR, Creutzberg M, Rodrigues AC, Casartelli AO, Freitas $\mathrm{AL}$. [Development and validation of an instrument for evaluating courses in higher education]. Est Aval Educ. 201;22(48):91-114. Portuguese.

4. Vituri DW, Matsuda LM. [Content validation of quality indicators for nursing care evaluation]. Rev Esc Enferm USP. 2009; 43(2):429-37. Portuguese.

5. Fonseca R, Silva P, Silva R. Acordo inter-juízes: o caso do coeficiente kappa. Lab Psicologia. 2007; 5(1):81-90.

6. Alexandre NM, Coluci MZ. [Content validity in the development and adaptation processes of measurement instruments]. Ciênc Saúde Coletiva. 2011;16(7):3061-8. Portuguese.

7. Morais GS, Costa SF, Fontes WD, Carneiro AD. [Communication as a basic instrument in providing humanized nursing care for the hospitalized patient]. Acta Paul Enferm. 2009; 22(3):323-7. Portuguese.

8. Dantas DV, Dantas RA, Costa IK, Torres GV. [Assistance protocol for venous ulcers patients: validation of contents]. Rev RENE. 2013;14(3):588-99. Portuguese.

9. Monteiro VG, Dantas DV, Costa IK, Mendes CK, Dias TY, Torres SM, et al. [Assistential and clinical aspects influence on chronicity of venous ulcers]. Rev Enferm UFPE. 2013; 7(5):1256-64.

10. Santos AA, Medeiros AB, Soares MJ, Costa MM. [Nursing students' knowledge of wound evaluation and treatment]. Rev Enferm UERJ. 2010; 18(4):547-52. Portuguese.

11. Ferreira AM, Andrade D. [Integrative review of the clean and sterile technique: agreement and disagreement in the execution of dressing]. Acta Paul Enferm. 2008; 21(1):117-21. Portuguese.

12. Alcoforado CL, Espirito Santo FH. [Knowledge and practices in nursing care to clients with wounds: the case of the city of Cruzeiro do Sul - Acre - Brazil]. REME - Rev Min Enferm. 2012;16(1):11-7. Portuguese.

13. Dantas DV, Torres GV, Dantas RA. [Assistance to individuals with ulcers: characterization of existing protocols in Brazil]. Cienc Cuid Saude. 2011;10(2):366-72. Portuguese.

14. Neves RS, Shimizu HE. [Analysis of the implementation of nursing assistance systematization in a rehabilitation unit]. Rev Bras Enferm. 2010; 63(2):222-9. Portuguese.

15. Moreira RA, Queiroz TA, Araújo MF, Araújo TM, Caetano JA. [Nurses' behaviour in the treatment of wounds in an intensive care unit]. Rev RENE. 2009; 10(3):45-51. Portuguese.

16. Oliveira SK, Queiroz AP, Matos DP, Moura AF, Lima FE. [Themes addressed in nursing consultation: integrative literature review]. Rev Bras Enferm. 2012; 65(1):155-61. Portuguese. 


\section{Appendix - Checklist Procedure}

Facility of practice observation: ( ) Health care unit ( ) Hospital ( ) Other
Monitoring by the preceptor: ( $)$ No ( ) Yes
Verification categories (0) Inadequate (1) Adequate

Verification categories (0) Inadequate (1) Adequate

\begin{tabular}{|c|c|}
\hline \multicolumn{2}{|c|}{ Procedures } \\
\hline 1 & Initial observations \\
\hline 1.1 & $\begin{array}{l}\text { Introduction to the person with skin lesion ( ) } \\
\text { Performs care indoors, ensuring the patient's privacy and making him/her comfortable ( ) } \\
\text { Explains the procedures to be performed ( ), (interview, physical examination, evaluation of the lesion, application of dressing, information). } \\
\text { Uses appropriate language ( ) } \\
\text { Requests permission and collaboration, if the patient can collaborate ( ) }\end{array}$ \\
\hline 1.2 & $\begin{array}{l}\text { Sanitizes hands before care ( ) } \\
\text { Removes jewelry ( ) } \\
\text { Performs simple hand hygiene with soap and water ( ) } \\
\text { Opens the tap and wets hands, avoiding leaning against the sink ( ) } \\
\text { Applies in the palm of hand liquid soap sufficient to cover all surfaces of the hands ( ) } \\
\text { Soaps palms of hands by rubbing them against each other ( ) } \\
\text { Scrubs palm of right hand against the back of the left hand, interlacing fingers and vice versa ( ) } \\
\text { Interlaces fingers and scrubs spaces between fingers ( ) } \\
\text { Scrubs the back of the fingers of one hand with the palm of the opposite hand, securing fingers with movement of backwards and forwards, and vice versa ( ) } \\
\text { Scrubs right thumb with the help of the palm of the left hand, using a circular movement and vice-versa ( ) } \\
\text { Rubs the fingertips and nails of left hand against the palm of right hand, closed in a clamshell, making circular motion and vice versa ( ) } \\
\text { Scrubs right thumb with the help of the palm of the left hand, using a circular movement and vice-versa ( ) } \\
\text { Rinses hands, removing soap residue. Avoids direct contact of soapy hands with the tap ( ) } \\
\text { Dries hands with disposable paper towel, beginning with the hands and then the wrists ( ) }\end{array}$ \\
\hline 2 & Evaluation of the patient and lesion \\
\hline 2.1 & $\begin{array}{l}\text { Takes medical history (in the first evaluation), collecting information about: } \\
\text { Identification (name, age, sex, address, nationality, marital status, skin color, income, education level, occupation ( ) } \\
\text { Emotional state ( ) } \\
\text { Clinical-history/history of disease (hypertension, diabetes, heart disease, venous/arterial insufficiency, allergies) ( ) } \\
\text { Drugs in use ( ) } \\
\text { Personal habits (smoking, alcohol consumption, physical activity, hours of sleep, leisure) ( ) } \\
\text { Family history ( ) } \\
\text { Personal hygiene ( ) } \\
\text { Nutritional state ( ) } \\
\text { Mobility (walking, walking with assistance, bedridden) ( ) } \\
\text { Bladder and bowel elimination ( ) } \\
\text { Complaint and duration of symptoms ( ) } \\
\text { History of current lesion and treatments performed ( ) } \\
\text { Characterization of previous lesions ( ) } \\
\text { Popular practice in the treatment of lesions ( ) } \\
\text { Identification of patient's caregiver and health care institution ( ) } \\
\text { Uses printed materials that guide medical history taking ( ) }\end{array}$ \\
\hline 2.2 & $\begin{array}{l}\text { Attention to risk factors: } \\
\text { Systemic (age, nutritional status, mobility, emotional state, general hygiene, incontinence, daily and work activity with risk of lesions, vascular insufficiency) ( ) } \\
\text { Local (edema, skin dehydration, pressure, infection, necrosis, humidity, trauma) ( ) } \\
\text { Invasive procedures ( ) } \\
\text { Use of drugs ( ) } \\
\text { Diseases associated ( ) } \\
\text { Scales used in the identification of risk factors ( ) }\end{array}$ \\
\hline 2.3 & $\begin{array}{l}\text { Performs physical examination of the person with skin lesion, from the head to the legs, making use of the techniques of inspection, palpation, percussion and auscultation (in the first assessment). } \\
\text { Physical examination directed in subsequent reviews. } \\
\text { The examination should include: } \\
\text { Identification of the characteristics of the skin, moisture, elasticity and turgor (attention to: mycoses, varicose veins, edema, lymphedema, pigmentation, hyperkeratosis, dermatitis, cyanosis, } \\
\text { temperature, dryness, lack of hair, calluses, deformities, cracks, protruding bony prominences) ( ) } \\
\text { Checks weight ( ) } \\
\text { Checks height ( ) } \\
\text { Calculation of body mass index ( ) } \\
\text { Palpation of peripheral pulses ( ) } \\
\text { Conducting sensitivity test ( ) } \\
\text { Measurement of the circumference of the calf and ankle ( ) } \\
\text { Calculation of Ankle Brachial Index ( ) }\end{array}$ \\
\hline 2.4 & Checks vital signs: pulse, respiratory rate, blood pressure and temperature ( ) \\
\hline 2.5 & $\begin{array}{l}\text { Assess the presence of pain associated with the lesion at baseline and subsequent evaluations before, during and after the completion of dressings ( ) } \\
\text { Collects detailed information on pain, seeking the location, pattern (type, duration, improvement, worsening, use of medication to control pain), the effect of pain on sleep and daily activities ( ） } \\
\text { Use of scales to assess pain intensity ( ） }\end{array}$ \\
\hline 2.6 & $\begin{array}{l}\text { Evaluates the wound, identifying (during baseline and subsequent evaluations): } \\
\text { Type of lesion (surgical incision, laceration, bruise, burn, pressure ulcers, neuropathic ulcers, arterial ulcers, venous ulcers) ( ) } \\
\text { Location of lesion ( ) } \\
\left.\text { Measurement of length (small - up to } 20 \mathrm{~cm}^{2} \text {; medium - from } 20 \text { to } 60 \mathrm{~cm}^{2} \text {; large - above } 60 \mathrm{~cm}^{2}\right)(\text { ) } \\
\text { Measurement of depth (surface - to the dermis, partially deep - down to the subcutaneous tissue, deep - muscle and adjacent structures) ( ) } \\
\text { Duration of lesion (acute - traumatic lesions that respond to treatment and heal without complication, chronic - of long duration and frequent recurrence) ( ) } \\
\text { Characteristics of the wound bed (granulation tissue, epithelialization, slough, necrotic) ( ) } \\
\text { Skin surrounding the lesion (normal, red, swollen, macerated, cyanotic, peeling, bullous, hematoma) ( ) } \\
\text { Edges of the lesion (detached, attached, washouts, macerated, whitish, hyperemia, epithelial) ( ) } \\
\text { Exudate (absent, serous, bloody, purulent, mixed patterns) ( ) } \\
\text { Volume of exudate (little - up to } 3 \text { gauze, medium - } 4 \text { to } 10 \text { gauze, a lot - over } 10 \text { gauze) ( ) } \\
\text { Odor (absent, grade I - felt when the dressing is opened; grade II without opening the dressing, grade III - foul and nauseating) ( ) } \\
\text { Exhibition of anatomical structures (muscle, tendon, blood vessels, bone, organs) ( ) } \\
\text { Evaluates the stage of tissue lesion in pressure ulcer (I. redness of intact skin; II. Bubbles/Lesions of small thickness (epidermis/dermis); III. Local skin lesion covering the subcutaneous site; IV. Total } \\
\text { lesion of the skin involving muscles, tendons and/or bones) ( ) } \\
\text { Uses instrument/printed form to guide the assessment of the lesion ( ) }\end{array}$ \\
\hline
\end{tabular}




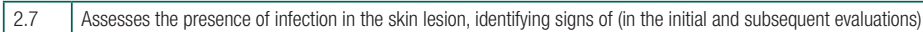

Increased pain (

Erythema surrounding lesion ( )

Edema ( )

Heat ( )

Purulent exudates ( )

Increased level of exudate ( )

Odor ( )

Systemic manifestations (hyperthermia, increased regional nodes, involution in wound healing) ( )

\begin{tabular}{|l|l}
\hline 2.8 & Identifies the need for and provides laboratory exams, considering the clinical picture of the person with skin lesion ( )
\end{tabular}

Requests laboratory tests in clinical protocol ( )

\begin{tabular}{|l|l}
\hline 3 & Care of the wound and surrounding skin \\
\hline 3.1 & Cleans wound \\
\hline
\end{tabular}

3.1 Cleans wound:

- Lesion healing by first intention:

Cleans the incision using two sides of gauze soaked with $0.9 \%$ saline solution, in unidirectional movements ( )

Cleans the edges of the lesion, using two sides of gauze soaked with $0.9 \%$ saline solution, in unidirectional movements ( )

Dries excess saline solution on the incision and edges, using two sides of gauze, in unidirectional movements ( )

Proceeds with mechanical cleaning of all surrounding skin with gauze moistened in $0.9 \%$ saline, in unidirectional movements. If dirt is present, cleans with antiseptics ( )

- Lesion healing by second and third intention:

Proceeds with mechanical cleaning of all surrounding skin with gauze moistened in $0.9 \%$ saline and unidirectional movements. If dirt is present, cleans with antiseptics (

Irrigates the edges of the lesion with jets of up to $0.9 \%$ saline solution (through a hole in the bottle with a $25 \times 8 \mathrm{~mm} 40 \times 12 \mathrm{~mm}$ gauge needle), warm (when possible) or at room temperature, or cold for bleeding lesions ( )

Irrigates the bed of the lesion with jets of up to $0.9 \%$ saline solution (through a hole in the bottle with a $25 \times 8 \mathrm{~mm} 40 \times 12 \mathrm{~mm}$ gauge needle), warm (when possible) or at room temperature, or cold for bleeding lesions ( )

3.2 $\quad$ Applies dressing with aseptic or sterile technique ( )

Lesion healing by first intention:

Sanitizes hands before applying dressing ( )

Collects all the material needed for the application of the dressing - $0.9 \%$ saline solution, procedure gloves, sterile gloves, sterile gauze, hypoallergenic tape or similar, plastic bag for disposal of the

material used ( )

Puts the patient with lesion in a comfortable position, maintains their privacy and explains what will be done (

Uses personal protective equipment ( )

Opens the dressing material without contaminating it $($ )

Removes the previous dressing using the procedure gloves that are then discarded $(\quad$ )

Carefully removes adhesive tapes with $0.9 \%$ saline solution, making sure that there was no adherence on the lesion, moistening with saline solution until it detaches, if this occurs ( )

Disposes of the dressing removed, along with gloves used, in a separate plastic bag for this purpose ( )

Proceeds with cleaning of the lesion ( )

Uses sterile gloves or tongs to handle the lesion ( ).

Occludes the lesion with sterile equipment (when there is exudation) ( )

Applies the dressing with hypoallergenic tape or similar ( )

Discards contaminated material in separate plastic bag for this purpose, organizing environment (

Sanitizes hands after applying dressing ( )

Lesion healing by second and third intention:

Sanitizes hands before applying dressing ( )

Collects all the material needed for application of the dressing, including $0.9 \%$ saline solution, procedure gloves, sterile gloves, sterile gauze, hypoallergenic tape or similar, crepe dressing, $40 \times 12 \mathrm{~mm}$

or $25 \times 8 \mathrm{~mm}$ needle, specific coverage chosen, plastic bag for disposal of the material used ( )

Puts the person with lesion in a comfortable position, protects their privacy and explains what will be done ( )

Uses personal protective equipment ( )

Opens the dressing material without contaminating it (

Removes the previous dressing using the procedure gloves which are then discarded in a plastic bag for this purpose ( )

Carefully removes adhesive tapes with $0.9 \%$ saline solution, making sure that there was no adherence onto the lesion, moistening with saline solution until it detaches, if this occurs ( )

Disposes of the dressing removed, along with gloves used, in a plastic bag for this purpose ( )

Proceeds with cleaning the lesion ( )

Uses sterile gloves or tongs to handle the lesion ( )

Places cover recommended for treatment of the lesion $($ )

Occludes the lesion with sterile equipment ( )

Applies the dressing with hypoallergenic tape or similar ( )

Discards the contaminated material in an appropriate place, organizing the environment ( )

Sanitizes hands after applying dressing ( )

3.3 Evaluates the need for debridement (chemical, mechanical, autolytic) of the necrotic and/or devitalized tissue, observed during initial or subsequent evaluation of the wound, according to the goals of treatment and the clinical condition of the patient with skin lesion, considering:

The recommendations (purulence, local and systemic infection, presence of foreign bodies, slough, necrosis) ( )

Contraindications (infected ulcer, ischemic ulcer, neoplastic ulcer, cavity ulcer with nerve exposure, patient with coagulation disorders) ( )

3.4 Choose the type of coverage (coverage is all material, substance or product that is applied to the wound to complete of the dressing):

Recommends coverage considering:

Recommendation (

Side effects ( )

Presence of pain associated with skin lesion ( )

Parameters related to the goal of treating the lesion (healing or controlling signs and symptoms) ( )

Characteristics of lesion: location of wound, vitality of tissue in the bed of the wound and surrounding area, conditions of edges, characteristics and amount of exudate, odor, presence of edema,

presence of symptoms and signs of local infection, lesion area (length $\mathrm{x}$ width), depth of the lesion, presence of tunnels, cavities or sinus (

Considers availability and the cost/benefit of coverage by the service or patient in performing the treatment $(\quad$ )

$4 \quad$ Referral and guidance to patient and family members/caregivers

4.1 $\quad$ Develops educational activities directed to the patient and family/caregiver, providing guidance regarding:

Diet ( )

Hygiene ( )

Hydration ( )

Skin care (

Risk factors for the development of lesions ( )

Clinical manifestations suggestive of worsening of lesion (pain, fever) ( )

Prevention of accident and trauma ( )

Prevention of complications ( )

Medications used in treatment ( )

Care with dressing ( )

Frequency of dressing change and encouragement of self-care( )

Carrying out activities of daily living ( )

Behavior followed in the treatment ( 
continuation

\begin{tabular}{|c|c|}
\hline 4.2 & $\begin{array}{l}\text { Identifies the need for and provides referral for the patient with skin lesion for medical evaluation (clinical evaluation or in the case of complications) ( ) } \\
\text { When inserted into the health care team and supported by clinical care protocol, identifies the need for and provides referral of patients with skin lesions for evaluation by an interdisciplinary team of } \\
\text { professionals: angiologist, endocrinologist, cardiologist, physiotherapist, nutritionist, social worker, psychologist ( ) }\end{array}$ \\
\hline 5 & Record and documentation \\
\hline 5.1 & 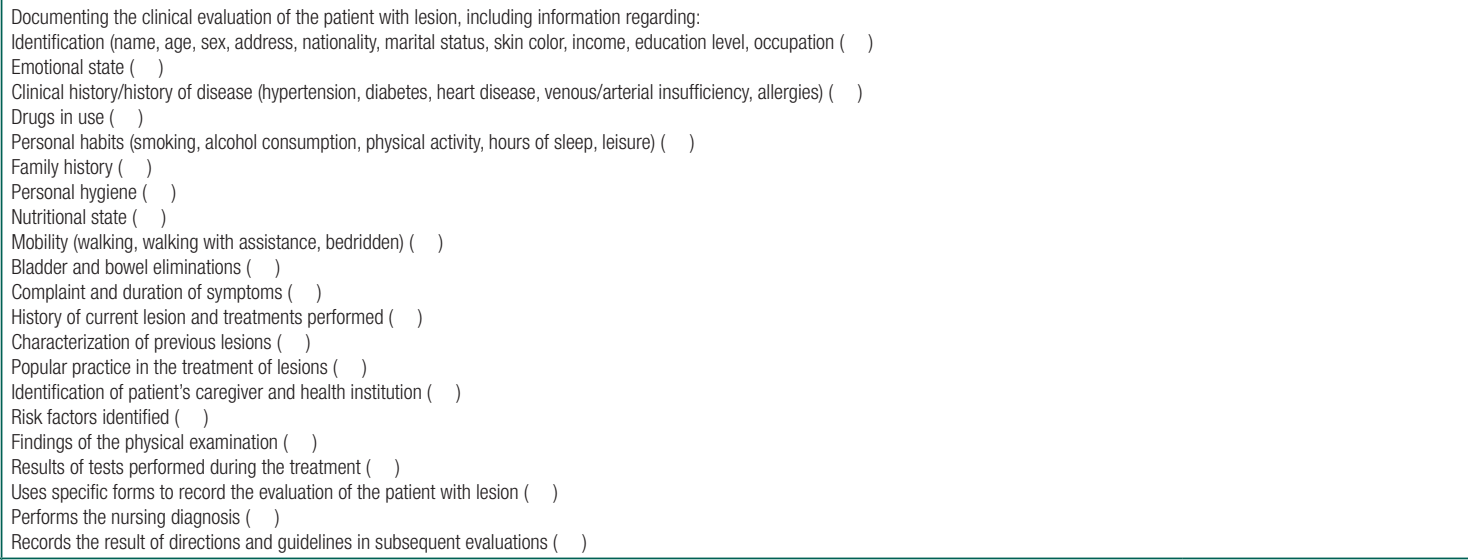 \\
\hline 5.2 & $\begin{array}{l}\text { Records information about evaluation of lesion characteristics: } \\
\text { Type of lesion ( ) } \\
\text { Location of lesion ( ) } \\
\text { Measurement of length of lesion ( ) } \\
\text { Measurement of depth of lesion ( ) } \\
\text { Duration of lesion ( ) } \\
\text { Characteristics of the bed of the wound ( ) } \\
\text { Skin surrounding lesion ( ) } \\
\text { Edge of lesion ( ) } \\
\text { Exudate ( ) } \\
\text { Volume of exudate ( ) } \\
\text { Odor ( ) } \\
\text { Exhibition of anatomical structures ( ) } \\
\text { Evaluates the stage of tissue lesion in pressure ulcers ( ) } \\
\text { Topical therapy performed (materials and products) ( ) } \\
\text { Complications during application of the dressing ( ) } \\
\text { Directions provided to the family member/caregiver and person with skin lesion ( ) } \\
\text { Uses specific forms to record the characteristics and evolution of the lesion ( ) } \\
\text { Performs the nursing diagnosis ( ) } \\
\text { Records the result of conduct and guidance in subsequent evaluations ( ) }\end{array}$ \\
\hline 6 & Final observations \\
\hline 6.1 & $\begin{array}{l}\text { Organizes the environment: } \\
\text { Discards used disposable material in garbage for infectious waste, using plastic bags intended for this purpose ( ) } \\
\text { Promotes the cleaning and disinfection of equipment and instruments used in care ( ) } \\
\text { Organizes the site of care ( ) }\end{array}$ \\
\hline 6.2 & $\begin{array}{l}\text { Sanitizes hands after care ( ) } \\
\text { Performs simple hand hygiene with soap and water after care( ) } \\
\text { Opens the tap and wets hands, avoiding leaning against the sink ( ) } \\
\text { Applies in the palm of hand liquid soap sufficient to cover all surfaces of the hands ( ) } \\
\text { Soaps palms of hands by rubbing them against each other ( ) } \\
\text { Scrubs palm of right hand against the back of the left hand, interlacing fingers and vice versa ( ) } \\
\text { Interlaces fingers and scrubs spaces between fingers ( ) } \\
\text { Scrubs the back of the fingers of one hand with the palm of the opposite hand, securing fingers, in a backwards and forwards movement, and vice versa ( ) } \\
\text { Scrubs right thumb with the help of the palm of the left hand, using a circular movement and vice versa ( ) } \\
\text { Rubs the fingertips and nails of left hand against the palm of right hand, closed in a clamshell, in a circular motion and vice versa ( ) } \\
\text { Scrubs left thumb with the help of the palm of the right hand, using a circular movement and vice versa ( ) } \\
\text { Rinses hands, removing soap residue. Avoids direct contact of soapy hands with the tap ( ) } \\
\text { Dries hands with disposable paper towel, beginning with the hands and then the wrists ( ) }\end{array}$ \\
\hline
\end{tabular}




\section{Questionnaire}

\begin{tabular}{|c|c|c|c|}
\hline 1 & \multicolumn{3}{|l|}{ PERSONAL IDENTIFICATION AND TRAINING/PROFESSIONAL QUALIFICATION } \\
\hline 1.1 & \multicolumn{2}{|l|}{ Age } & years \\
\hline 1.2 & \multicolumn{2}{|l|}{ Sex } & ( ) male ( ) female \\
\hline 1.3 & \multicolumn{2}{|c|}{ Undergraduate disciplines in which you had access to the content (theory and practice) on wounds } & \\
\hline 1.4 & \multicolumn{2}{|c|}{ Conducted further studies on content about wounds in addition to what was taught in course subjects } & ( ) No ( ) Yes \\
\hline 1.5 & \multicolumn{2}{|l|}{ Opportunity to provide care to people with wound } & $\begin{array}{ll}( & \text { No } \\
( & \text { In the subjects of the course } \\
( & \text { At work } \\
( & \text { In field practice } \\
( & \text { ) Others }\end{array}$ \\
\hline 1.6 & \multicolumn{2}{|l|}{ Observed the care of patients with wounds } & $\begin{array}{ll}( & \text { No } \\
( & \text { In the subjects of the course } \\
( & \text { At work } \\
( & \text { In field practice } \\
( & \text { ) Others }\end{array}$ \\
\hline 1.7 & \multicolumn{2}{|l|}{ Participated in extracurricular courses or training on wounds } & 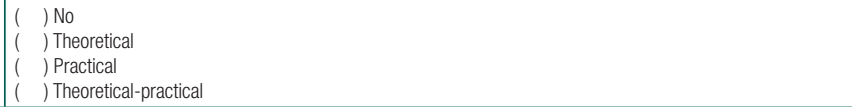 \\
\hline 1.8 & \multicolumn{2}{|l|}{ Hourly load of training or course } & hours \\
\hline 2 & \multicolumn{3}{|l|}{ KNOWLEDGE ABOUT NURSING CARE FOR PATIENTS WITH SKIN LESIONS } \\
\hline \multicolumn{4}{|c|}{ Mark with an " $X$ " the response that best answers the questions below: } \\
\hline 2.1 & $\begin{array}{l}\text { What actions should be taken in the evaluation stage of a patient } \\
\text { with skin lesion? }\end{array}$ & \multicolumn{2}{|c|}{$\begin{array}{l}\text { 1. Conduct Interview (anamnesis) and physical examination. } \\
\text { 2. Identify risk factors and check vital signs. } \\
\text { 3. Evaluate the lesion and check for signs and symptoms of infection. } \\
\text { 4. Identify the need for and provide additional exams. } \\
\text { 5. ALL OF THE ABOVE. }\end{array}$} \\
\hline 2.2 & $\begin{array}{l}\text { Which aspects should be considered when evaluating the charac- } \\
\text { teristics of the skin lesion? }\end{array}$ & \multicolumn{2}{|c|}{$\begin{array}{l}\text { 1. Type and duration of lesion. } \\
\text { 2. Characteristics of the bed and edges of the lesion. } \\
\text { 3. Presence of odor, appearance and volume of exudate. } \\
\text { 4. Location, depth and width of lesion. } \\
\text { 5. ALL OF THE ABOVE. }\end{array}$} \\
\hline 2.3 & $\begin{array}{l}\text { Which signs of infection should be considered when evaluating the } \\
\text { characteristics of the skin lesion? }\end{array}$ & \multicolumn{2}{|c|}{$\begin{array}{l}\text { 1. Cool skin around the lesion, pain, exudate. } \\
\text { 2. Necrosis, edema, exudate. } \\
\text { 3. PAIN, ERYTHEMA, EDEMA AND HEAT, INCREASED AND PURULENT EXUDATE, ODOR. } \\
\text { 4. Bleeding, pain, cold skin around the lesion. } \\
\text { 5. Necrosis, pain, edema. }\end{array}$} \\
\hline 2.4 & $\begin{array}{l}\text { Which aspects should be considered when choosing the dressing to } \\
\text { be applied onto the skin lesion? }\end{array}$ & \multicolumn{2}{|c|}{$\begin{array}{l}\text { 1. Time of evolution of the lesion, presence of infection on the lesion. } \\
\text { 2. Lesion location and type of skin lesion. } \\
\text { 3. Depth of the lesion, presence of pain. } \\
\text { 4. Length of the lesion, presence of pain. } \\
\text { 5. ALL OF THE ABOVE. }\end{array}$} \\
\hline 2.5 & $\begin{array}{l}\text { During care of the wound and surrounding skin, what is the ade- } \\
\text { quate procedure to perform when applying the dressing? }\end{array}$ & \multicolumn{2}{|c|}{$\begin{array}{l}\text { 1. Change the cover used in treatment without cleaning the lesion, using clean dressing technique for all types of lesions. } \\
\text { 2. CLEAN THE LESION WITH 0.9\% SALINE SOLUTION PRIOR TO CHANGING THE DRESSING. } \\
\text { 3. Remove previous dressing with } 70 \% \text { alcohol or ether, clean the lesion with } 0.9 \% \text { saline solution, and place the cover used in the treatment. } \\
\text { 4. Change the cover and then clean the lesion. } \\
\text { 5. Clean open lesions with antiseptic solution, leaving uncovered. }\end{array}$} \\
\hline 2.6 & $\begin{array}{l}\text { In the initial and subsequent evaluation of the skin lesion, the nurse } \\
\text { should be aware of the wound characteristics that indicate the need } \\
\text { to perform debridement. What are these characteristics? }\end{array}$ & \multicolumn{2}{|c|}{$\begin{array}{l}\text { 1. PRESENCE OF SLOUGH, FOREIGN BODIES, NECROSIS, PURULENCE, LOCAL INFECTION. } \\
\text { 2. Cavity ulcers with nerve exposure. } \\
\text { 3. Ulcer on terminally-ill patient. } \\
\text { 4. Ulcer on lower limbs with presence of granulation tissue. } \\
\text { 5. Ulcer on lower limbs in process of epithelialization. }\end{array}$} \\
\hline 2.7 & $\begin{array}{l}\text { When recommending the coverage to be used in the treatment of } \\
\text { the lesion, what should the nurse consider? }\end{array}$ & \multicolumn{2}{|c|}{$\begin{array}{l}\text { 1. KNOW THE RECOMMENDATION, CONTRAINDICATION, CHANGING PERIOD, COST AND BENEFIT OF THE COVER IN RELATION TO THE CHARACTERIS- } \\
\text { TICS OF THE LESION TO BE TREATED. } \\
\text { 2. Choose any cover considering the type of lesion. } \\
\text { 3. Recommend the cover to be used in the treatment of the lesion considering only the stage in the healing process. } \\
\text { 4. Indicate the cover that is appropriate for the treatment of all kinds of lesion. } \\
\text { 5. All of the above. }\end{array}$} \\
\hline 2.8 & $\begin{array}{l}\text { What debriding action products are used in the topical treatment } \\
\text { of skin lesions? }\end{array}$ & \multicolumn{2}{|c|}{$\begin{array}{l}\text { 1. Chlorhexidine, calcium alginate. } \\
\text { 2. PAPAIN, HYDROGEL. } \\
\text { 3. Activated charcoal, silver sulfadiazine. } \\
\text { 4. Semi-permeable film, essential fatty acids. } \\
\text { 5. Povidone-iodine, calcium alginate. }\end{array}$} \\
\hline 2.8 & $\begin{array}{l}\text { What guidelines should be provided to patients with skin lesions } \\
\text { and their relative/caregiver for continuing care? }\end{array}$ & \multicolumn{2}{|c|}{$\begin{array}{l}\text { 1. Personal hygiene, nutrition, risk factors for the development and exacerbation of skin lesions. } \\
\text { 2. Factors that interfere with the healing process, and self-care of the dressing. } \\
\text { 3. Periodicity of application of the dressing, encouraging self-care and the performance of activities of daily living. } \\
\text { 4. Problems in wound healing and conduct adopted and implemented in the treatment. } \\
\text { 5. ALL THE ANSWERS CONTAIN IMPORTANT DIRECTIONS FOR PATIENTS WITH SKIN LESIONS AND THEIR FAMILY MEMBERS AND CAREGIVERS. }\end{array}$} \\
\hline 2.10 & $\begin{array}{l}\text { When completing the record and documentation of the care pro- } \\
\text { cess for a patient with lesion, what should be done? }\end{array}$ & \multicolumn{2}{|c|}{$\begin{array}{l}\text { 1. RECORD THE EVALUATION OF THE PATIENT WITH LESION, FROM THE INITIAL EVALUATION OF THE LESION AND ITS FEATURES THROUGHOUT TREAT- } \\
\text { MENT, THE DIRECTIONS PROVIDED TO THE PATIENT AND THEIR FAMILY MEMBER/CAREGIVER. } \\
\text { 2. Record results of laboratory tests and referrals to other health professionals. } \\
\text { 3. Document evolution of lesion throughout treatment and preventive care. } \\
\text { 4. Record the initial clinical evaluation of the patient with skin lesion. } \\
\text { 5. Record the initial evaluation of the lesion and its features throughout the treatment }\end{array}$} \\
\hline
\end{tabular}

